\title{
Comparison and Analysis of the Modes of Legal Innovation and Entrepreneurship Education in Universities
}

\author{
Xiaoxian $\mathrm{Pu}^{1, *}$ \\ ${ }^{1}$ School of Law, Humanities and Sociology, Wuhan University of Technology, Wuhan, Hubei, China \\ *Corresponding author. Email: 602489814@qq.com
}

\begin{abstract}
The purpose of this paper is to further improve the ability of cultivating innovative and entrepreneurial talents for law major in Chinese universities and to improve the purpose of cultivating talents. The methods of questionnaire survey and case tracking were adopted. The problems existing in the current cultivation mode of legal innovation and entrepreneurship talents are found, such as the backward teaching methods of legal innovation and entrepreneurship, insufficient implementation of legal innovation and entrepreneurship education, and the inability of legal innovation and entrepreneurship to adapt to the new situation. This paper finds out the reasons for the problems existing in the current training mode of law innovation and entrepreneurship talents, and puts forward several countermeasures to improve the training mode of law innovation and entrepreneurship talents, such as conducting classified training, optimizing the curriculum system, strengthening the faculty and optimizing the assessment method according to the needs of talent training.
\end{abstract}

Keywords: Legal Innovation and Entrepreneurship Education, talent training model, comparison

\section{THE ORIGIN AND DEVELOPMENT STAGE OF INNOVATION AND ENTREPRENEURSHIP EDUCATION IN CHINESE UNIVERSITIES}

Innovation and entrepreneurship education is a reform of the talent training model first proposed by Western countries. The practical experience of innovation and entrepreneurship education in these countries is also earlier than that of Chinese universities. The United States is one of the earliest countries that advocated and implemented the cultivation of innovative and entrepreneurial talents. By recruiting diversified educational objects, implementing multi-disciplinary teaching content, innovating "learning by doing" practical teaching methods, and establishing high-level teachers, etc. The United States has achieved remarkable results in the cultivation of innovative and entrepreneurial talents. Entrepreneurship education in European countries is more integrated into applied science and technology universities. Entrepreneurship education has become a very important part of the mature educational philosophy and system of universities of applied sciences in Germany. With the support of financial funds, the University of Cambridge in the United Kingdom has set up a special entrepreneurship center to promote entrepreneurship and encourage Universities form an entrepreneurial culture and provide practical support for those who are willing to start a business; France has established entrepreneurial alliances through the establishment of entrepreneurial alliances between universities to play a central role in promoting entrepreneurship, cultivating entrepreneurial talents, and coaching students in entrepreneurship.

In 1991, Japan held an international conference on entrepreneurship and innovation education. The conference proposed that innovation and entrepreneurship education is to train people with the most pioneering personality, including pioneering spirit, adventurous spirit, and entrepreneurial ability. This definition has become an important basis for many domestic researchers to analyze, understand and define innovation and entrepreneurship education.

It can be found that compared with the traditional talent training model, innovation and entrepreneurship education is a practical education in a substantial sense. It focuses on training talents in three aspects or factors: entrepreneurial awareness, innovative thinking and entrepreneurial ability. From the perspective of origin, the implementation of innovation and entrepreneurship education in Chinese universities began at the end of the 20th century. [1] In 1998, Tsinghua University held the first Tsinghua University Entrepreneurship Planning Competition. In 2002, my country's college entrepreneurship education was officially launched. The Ministry of Education identified 9 colleges and universities, including Tsinghua University, Beihang University, and Renmin University of China, as pilot institutions for entrepreneurship education, and gained valuable experience in the promotion and development. 
Since 1998, the innovation and entrepreneurship education promoted by domestic universities has gone through more than 20 years. Some researchers have summarized the progress of my country's innovation and entrepreneurship education into four stages in chronological order: [2] The first stage, from 1998 to 2014, was the enlightenment period of innovation and entrepreneurship education. The researcher pointed out that the main feature of this stage was that the "work-study" of college students evolved into "entrepreneurship". Some colleges and universities opened "innovation classes" and General courses to cultivate entrepreneurial spirit. The second stage is from June 2014 to June 2016, especially after the State Council issued "Circular 36", [3] With a large number of innovation and entrepreneurship education policies issued by the Ministry of Education and local education authorities, the era of "mass entrepreneurship and innovation" has officially arrived. The third stage is the beginning of 2017. Innovation and entrepreneurship education has aroused widespread heated discussion among universities and the society. For example, is the innovation and entrepreneurship education in universities for cultivating entrepreneurs or educating people? Most people think that university innovation Entrepreneurship education is definitely not to train a few entrepreneurs. The essence of education is to educate people. This stage is the return period of the understanding of the connotation of innovation and entrepreneurship education. The fourth stage is from 2017 to the present. With the positioning of the "19th National Congress" in the "new era" of the country, building an innovative country has become the only way for China to become stronger, and the cultivation of innovative and entrepreneurial talents has become an important task for universities during the "13th Five-Year Plan" period. The study believes that innovation and entrepreneurship education will usher in unprecedented opportunities for vigorous development at this stage.

\section{SEVERAL MODES OF LEGAL INNOVATION AND ENTREPRENEURSHIP EDUCATION IN UNIVERSITIES}

The law major is one of the most practical majors in the field of humanities and social sciences. With its professional attributes and advantages, in the process of vigorously advocating and promoting college students' innovation and entrepreneurship education, it is not only possible to cultivate a large number of outstanding independent entrepreneurs, but also And it can also create indispensable entrepreneurial legal services in various industries.

In fact, the state provides strong motivation and support for colleges and universities to promote innovation and entrepreneurship education through various methods such as policy support and resource investment. However, how each school and different majors should implement their own innovation and entrepreneurship education is different. Colleges and universities and majors have different plans, which form different experience models. In terms of different schools and majors, innovation and entrepreneurship education has some common points, such as adjusting the training plan, strengthening the teaching staff, reforming the previous curriculum and constructing related platforms, etc. However, in the process of carrying out the above work, local governments There are differences in specific practices.

The same is true for innovation and entrepreneurship education in law. In the process of promoting innovation and entrepreneurship education in various universities' law majors, different paths and models have been formed. The more typical examples are the "four-three-two" innovation and entrepreneurship work system of China University of Political Science and Law and the "integrated, multidimensional and binary integration" talent training of Renmin University Model, Jishou University's "Five Union" talent training model, Henan University of Science and Technology's "Four Combination" talent training model, and Fujian Agriculture and Forestry University's "Three Innovation" talent training model.

China University of Political Science and Law is an important base for training legal talents in my country, and it is also one of the pioneers in promoting innovation and entrepreneurship education in law. Compared with other universities, China University of Political Science and Law has established a comprehensive training model for innovative and entrepreneurial talents in law: perfecting the top-level design, perfecting the curriculum system, building a superior platform, and providing solid guarantees. [4]China University of Political Science and Law adopted the "four three two" entrepreneurial work system in the process of talent training, that is, establishing a four-level entrepreneurial guidance system of "education, training, practice, and support" to form a scientific and reasonable talent training logic; graded in the curriculum design The three-level advanced course system of "foundation of entrepreneurship, practice of entrepreneurship, and practice of entrepreneurship" is promoted in an orderly manner; at the same time, in the construction of the teaching team, the system of entrepreneurship tutors of "combination of professional and concurrent, school and college" is established and improved. Through multiple system guarantees, with its own long experience in running a school and abundant social resources, China University of Political Science and Law has achieved very good results in the cultivation of legal innovation and entrepreneurial talents. As of December 2018, China University of Political Science and Law has held five consecutive "Law Students Entrepreneurship Practice Courses". A teaching team composed of teachers, corporate executives, and lawyers has greatly strengthened students' innovative awareness and entrepreneurial capabilities.

At the same time, other domestic political and law colleges, such as East China University of Political Science and Law, Shandong University of Political Science and Law, and other domestic professional law schools have also explored this aspect. They are also the 
innovative and entrepreneurial talent training model of political and law colleges. Experience provides a valuable reference for the reform of the talent training model of law majors in other universities.

Renmin University is one of the domestic universities that promoted the innovation and entrepreneurship education of law majors earlier. Renmin University Law School relies on the student KAB Entrepreneurship Club and Innovation Association to carry out competitions, salons, large forums, innovation forums, entrepreneurial pioneer reports and other activities. Establish an entrepreneurial fund to build a two-level, full-time and part-time entrepreneurial mentor team. In the process of advancing legal innovation and entrepreneurship education, Renmin University Law School is based on the update of legal knowledge, with curriculum system reform as the core, and practical project innovation as the backing, building an "integrated and multidimensional" talent training support mechanism, and strives to develop and meet individuality Specialized training projects for the needs of globalization, the production of teaching materials based on major practical issues, the construction of a smooth transformation platform for scientific research and teaching, and the dual integration of legal knowledge education and practical education, focusing on me, inclusive, highlighting characteristics, and exploring" "Integrated, multi-dimensional and dual-integrated" newtype legal talent training mechanism to deepen the reform and innovation of legal education, Facts show that this event model has also achieved impressive results.

Different from China University of Political Science and Law and Renmin University, Jishou University is a local university. In the process of promoting and implementing the innovation and entrepreneurship education reform of law majors, adjusting and optimizing the original talent training model, its resources and platforms are not the same as the aforementioned famous universities. However, Jishou University is one of the local colleges and universities that actively promotes innovation and entrepreneurship education reform. The exploration mode and practical experience of the innovation and entrepreneurship education of Jishou University's law major can be summarized as the five combinations of "production, teaching, research and application". The fivecombination model of "production, teaching, research and application" is guided by the goal of cultivating innovative and applied legal talents with strong innovative and practical ability, and is guided by deepening the education mechanism of cooperation with industry and industry to establish a high-level theory and practice. Based on the team of teachers and modern practical teaching system, it focuses on strengthening students' professional practice and scientific research and innovation ability training, and promotes students' innovation and practice ability selfshaping and application practice as the basis to achieve innovation, practice, education, learning and application. Integration, and then realize the training of legal talents with distinctive innovation and entrepreneurship education
Through the long-term practice and exploration of education and teaching reform, the Law School of Henan University of Science and Technology has promoted the "four combinations" innovative and entrepreneurial talents combining in-class and extra-curricular, in-school and outof-school, theory and practice, and in and out of jurisdiction. The training mechanism is adapted to the society's demand for innovative and entrepreneurial law/legal talents, and has achieved significant teaching effects in practice. [5] A teacher from the Faculty of Law of Fujian Agriculture and Forestry University pointed out that for agricultural colleges and universities like Fujian Agriculture and Forestry University, there are many drawbacks in the undergraduate law education that uses the judicial examination as the baton. It completely abandons the school's advantages and characteristics of running a school, and it cannot be The country and society have cultivated enough talents in agriculture and forestry law. The teacher believes that the goal of undergraduate law education should be positioned as general education. In the process of innovation and entrepreneurship education reform, the undergraduate teaching of law in higher agricultural and forestry colleges should combine traditional law undergraduate teaching with agricultural and forestry specialty, and innovate curriculum systems, teaching methods and practical teaching links to cultivate special agricultural and forestry laws that truly meet the needs of social development Talent [6].

By analyzing the practical experience of the abovementioned different schools, it can be found that the innovation and entrepreneurship education of the law major has been valued by universities from all over the world in the process of promotion and implementation. Like the cultivation of innovative and entrepreneurial talents in other majors, the cultivation of innovative and entrepreneurial talents in law mostly starts from the construction of subject system, construction of teachers, and construction of practical platforms to cultivate students' entrepreneurial awareness and innovative spirit. However, due to various comprehensiveness Due to the existence of factors, the actual results of the construction of industrial innovative talents in different universities will be different to a certain extent.

\section{EVALUATION AND ANALYSIS OF THE EDUCATIONAL MODE OF INNOVATION AND ENTREPRENEURSHIP IN LAW IN COLLEGES AND UNIVERSITIES}

\subsection{The Achievements of the Existing Legal Innovation and Entrepreneurial Talent Training Model}

China University of Political Science and Law has constructed a full range of innovative and entrepreneurial talent training models for law majors in the practice of 
promoting innovation and entrepreneurship education in law majors. The school has formulated a new standard for measuring the quality of talent training, and incorporated innovation and entrepreneurship as an evaluation standard into the evaluation system to improve students' innovation and entrepreneurship capabilities and achieve their allround development; successively established the "Student Employment and Entrepreneurship Guidance Service Center" and the "China University of Political Science and Law Entrepreneurship" College" [8] , Provide special instructional work for students' entrepreneurship, and provide scientific and effective advice on legal issues encountered by students, which is conducive to the smooth progress of employment and entrepreneurship of college students; overall planning of the key tasks of school entrepreneurship education, and perfect innovation and entrepreneurship education curriculum system , Combining innovation and entrepreneurship education with legal education to adapt to the current new situation and changes; the mutual employment plan between the school and the legal practice department has made teachers' innovation and entrepreneurship education and teaching ability increasingly improved.

In the process of actively promoting innovation and entrepreneurship education, Renmin University based on the advantages of institutions and absorbing beneficial experience, the relevant education level of the school has reached a new height. The first law school in the country established by the school has carried out in-depth cooperation with the Supreme People's Procuratorate and the Supreme People's Court, combining knowledge education with practical education, improving the school's ability to cultivate talents and the ability to target students with special talents. In order to adapt to the changes in the new situation, reform the content of the curriculum system, conduct cross-research on new legal issues such as the Internet and big data, update teaching content, add new disciplines, introduce new teaching materials, use legal knowledge to solve emerging cutting-edge scientific and technological issues, and promote law Renewal of education.

Through the implementation of the five-combination talent training model of "production, teaching, research and application", Jishou University has achieved fruitful results in the training of legal talents, and the number of legal professionals with good innovative and practical capabilities has been increasing, which is particularly important for the construction of the rule of law in my country. It is the contribution to the construction of the rule of law in the Wulingshan area. The school actively promotes the reform of innovation and entrepreneurship education model, cultivates innovative legal talents based on the needs of local legal system construction, focuses on strengthening students' professional practice and scientific research and innovation ability training, clarifies training goals, focuses on training practical legal talents.

The Law School of Henan University of Science and Technology has carried out an exploratory reform of the training mechanism for innovative and entrepreneurial talents, forming a "four-in-one" training model. The school has allocated sufficient hardware resources to improve the cultivation of multiple abilities of French students in innovation, entrepreneurship, learning and practice, such as Establish mock courts and intellectual property laboratories, as well as matching software resources such as a reasonable proportion of teachers.

In the process of innovation and entrepreneurship education reform, the Law Department of Fujian Agriculture and Forestry University took advantage of the unique advantages of higher agricultural and forestry colleges to develop a talent training model with characteristics of agricultural and forestry colleges. The school combines traditional law undergraduate teaching with specialties in agriculture and forestry, focusing on agricultural law, building a complete agricultural law teaching system, using its disciplinary background advantages, achieving interdisciplinary exchanges, and cultivating a large number of practical applications that adapt to the construction of new rural areas and social development Comprehensive agricultural and forestry legal talents; the school has also established a rural rule of law research center, which leads students to go deep into the countryside in practical courses, cultivates applied legal talents serving "agriculture, rural areas, and farmers", and provides a large number of pragmatics for the development of grassroots law Professional legal talent.

\subsection{Problems Existing in the Training Model of Innovative and Entrepreneurial Talents in Law}

\subsubsection{The backward teaching methods of law innovation and entrepreneurship}

The law major is a rapidly developing major. Relying on traditional teaching methods cannot fully adapt to the emergence of new social frontier scientific and technological issues; colleges and universities have not provided diversified teaching methods, such as observation court trials, actual case teaching, mock courts and other new teaching methods. Students have little interaction with teachers in the classroom and are motivated Not high; the practice environment in China's universities is not perfect, students cannot obtain practical judicial practical experience from classroom teaching, and the backward teaching methods of innovation and entrepreneurship have led to the failure of students' innovative practical ability to be improved.

\subsubsection{Insufficient implementation of legal innovation and entrepreneurship education}

Although Chinese colleges and universities have modified the plan for training innovative and entrepreneurial talents, 
they lacked the ability to execute in the process of implementation, and the actual implementation effect was not good. For example, some colleges and universities have not actually opened the necessary practical courses, and students have mastered the theoretical foundation, but have not mastered the actual ability to solve complex problems; some colleges and universities have opened innovative and entrepreneurial courses, but the implementation is not optimistic, and they have not considered whether the training system is scientific. It also ignores the importance of systematically cultivating the practical ability of innovation and entrepreneurship, which leads to the fact that the practical ability of students cannot be substantially improved.

\subsubsection{Legal innovation and entrepreneurship cannot adapt to the new situation}

With the rapid development of society and the improvement of laws, legal education must continue to innovate, build a complete legal innovation and entrepreneurship system, and solve the frontier issues of law. Traditional legal teaching methods often like to learn from foreign outstanding legal achievements, but in the process of learning, they neglect to combine with China's specific practice, resulting in the ineffective connection of knowledge education and practical education, and students lack the ability to handle actual legal cases. With the continuous advancement of science and technology, more and more new situations have emerged, which requires law students to have sufficient innovation and practical spirit to discover and solve new problems. However, the lagging nature of the school's innovation and entrepreneurship courses cannot ensure that law students use their knowledge to solve new scientific and technological problems. In this way, the students trained by the law school can not meet the needs of social development if they really go out of the campus to practice, and they cannot quickly adapt to the new socialism with Chinese characteristics. situation.

\section{COUNTERMEASURES TO IMPROVE THE TRAINING MODE OF LAW INNOVATION AND ENTREPRENEURSHIP TALENTS}

\subsection{Conduct Classified Training, Optimize the Curriculum System, and Enhance the Faculty Strength}

The innovative legal education should constantly adjust the talent training program in keeping pace with The Times, and conduct classified training for students, so as to cultivate the students that are suitable for close combination with school-running characteristics or advantageous majors, and promote the training of innovative entrepreneurial talents in theoretical research, enterprise legal affairs, public security law practitioners and law entrepreneurs. Different types of talents inevitably require teaching units to adopt different training modes, set up different curriculum systems and equip different teachers.

\subsection{It is Closely Combined with School- running Characteristics or Competitive Specialties to Promote the Cultivation of Innovative and Entrepreneurial Talents}

Law professional creative talent cultivation with characteristics and advantages of specialty in colleges and universities should, on the basis of the organic combination of culture can reflect the school characteristics, with advantages of professional development needs of new legal talent, this can make the students not only gain a unique advantage in employment and entrepreneurship, can also from the law department has gradually formed a unique creative talent training mode.

\subsection{Optimize the Assessment Method According to the Talent Training Needs}

Curriculum assessment is an important link in the teaching process. The construction of curriculum assessment system and the selection of assessment methods are one of the core contents of talent training plan. It is necessary to construct a multi-way assessment system, which combines the paper-based examination with the non-paper-based practical operation assessment. Pay attention to the process of the specific teaching links and the final results of the examination; we should attach equal importance to the memory assessment of basic knowledge and the application of higher level abilities.

\section{CONCLUSION}

In the past ten years, domestic universities have vigorously promoted innovation and entrepreneurship education, and the law school is no exception. According to the difference in practice, the law majors in colleges and universities have formed a number of different implementation paths and talent training models in the process of promoting innovation and entrepreneurship education, such as the "four-three-two" innovation and entrepreneurship work system of China University of Political Science and Law, and the "Integrated, multi-dimensional and binary integration talent training model, Jishou University's "five union" model, Henan University of Science and Technology's "four combinations" model, and Fujian Agriculture and Forestry University's "three innovations" model. Through comparative analysis, it is found that the 
advantages and problems of these models coexist. In-depth discussion of this problem can provide a valuable reference for the promotion of innovation and entrepreneurship education in other domestic law majors. At present, when promoting innovation and entrepreneurship education in domestic law major, there are still significant deficiencies in its talent training mode, such as backward teaching methods of law innovation and entrepreneurship, insufficient implementation of law innovation and entrepreneurship education, and law innovation and entrepreneurship cannot adapt to the new situation. In order to further enhance the ability of cultivating innovative and entrepreneurial talents in law major in Chinese universities and improve the talent cultivation plan, it should be clear from the training purpose that the goal of cultivating innovative and entrepreneurial talents is to cultivate the innovative spirit and entrepreneurial consciousness of law science students. We should carry out classified training for law students, improve the curriculum, consolidate the curriculum content of innovation and entrepreneurship, and optimize the teaching staff. In addition, the law majors of colleges and universities should be encouraged to combine with the school-running characteristics or advantages of the colleges and universities, so as to innovate the talent types and optimize the talent training mode. Finally, in the cultivation of innovative and entrepreneurial talents, the law major must reshape the course assessment system and adopt diversified assessment methods, so as to evaluate the comprehensive quality and ability of students more accurately.

\section{REFERENCES}

[1] Science and Technology Daily, 2018, How to do "double innovation" education? "Hua Gong Mode" gives these inspirations!, People's Daily Online: http://edu.people.com.cn/n1/2018/0809/c105330218837.html

[2] F.L. Zhang, What is innovation and entrepreneurship education 4.0?, Development China Net: ttp://sczg.china.com.cn/2017-

11/16/content_40070867.htm

[3] The full name of Document 36 is the "Implementation Opinions of the General Office of the State Council on Deepening the Reform of Innovation and Entrepreneurship Education in Colleges and Universities", which was released in 2015. The main content is to emphasize the great significance of innovation and entrepreneurship education and affirm the great achievements of innovation and entrepreneurship education in my country's universities in recent years. Mainly put forward important opinions and suggestions in response to the outstanding problems existing in innovation and entrepreneurship education.

[4] J.F. Zhong, China University of Political Science and Law deeply promotes innovation and entrepreneurship education reform, Guangming Net: http://www.moe.gov.cn/jyb_xwfb/s6192/s133/s149/201 607/t20160729_273288.html

[5] P. Li, The Law School of Renmin University of China explores the "one body, multi-dimensional and binary integration" new socialist legal talent training model, Guangming Net:

http://www.gmw.cn/xueshu/2018-

04/19/content_28398818.htm

[6] J.F.Zhang,2019, Practical exploration of "four combinations" innovation and entrepreneurship talent training mechanism for law students, Heilongjiang Education (Higher Education Research and Evaluation),04:67-69.

[7] Y.Zhang, 2016,The new orientation of law undergraduate teaching in higher agricultural and forestry colleges__ Taking Fujian Agriculture and Forestry University as an example, Journal of Lanzhou Higher Education College, 32(07):106-108.

[8] China University of Political Science and Law Deepening the Reform and Implementation of Innovation and Entrepreneurship Education, Ministry of Education Network: http://www.moe.gov.cn/s78/A08/gjs_left/s3854/cxcyjy _ssfa/201605/t20160516_244075.html 